\title{
Evaluation of suspected malignant hyperthermia events during anesthesia
}

\author{
Frank Schuster*, Stephan Johannsen, Daniel Schneiderbanger and Norbert Roewer
}

\begin{abstract}
Background: Malignant hyperthermia (MH), a metabolic myopathy triggered by volatile anesthetics and depolarizing muscle relaxants, is a potentially lethal complication of general anesthesia in susceptible patients. The implementation of modern inhalation anesthetics that research indicates as less potent trigger substances and the recommended limitations of succinylcholine use, suggests there may be considerable decline of fulminant $\mathrm{MH}$ cases. In the presented study, the authors analyzed suspected MH episodes during general anesthesia of patients that were referred to the Wuerzburg MH unit between 2007 and 2011, assuming that MH is still a relevant anesthetic problem in our days.

Methods: With approval of the local ethics committee data of patients that underwent muscle biopsy and in vitro contracture test (IVCT) between 2007 and 2011 were analyzed. Only patients with a history of suspected MH crisis were included in the study. The incidents were evaluated retrospectively using anesthetic documentation and medical records.

Results: Between 2007 and 2011 a total of 124 patients were tested. 19 of them were referred because of suspected $\mathrm{MH}$ events; 7 patients were diagnosed $\mathrm{MH}$-susceptible, $4 \mathrm{MH}$-equivocal and $8 \mathrm{MH}$-non-susceptible by IVCT. In a majority of cases masseter spasm after succinylcholine had been the primary symptom. Cardiac arrhythmias and hypercapnia frequently occurred early in the course of events. Interestingly, dantrolene treatment was initiated in a few cases only.
\end{abstract}

Conclusions: $\mathrm{MH}$ is still an important anesthetic complication. Every anesthetist must be aware of this lifethreatening syndrome at any time. The rapid onset of adequate therapy is crucial to avoid major harm and possibly lethal outcome. Dantrolene must be readily available wherever $\mathrm{MH}$ triggering agents are used for anesthesia.

Keywords: Malignant hyperthermia, In vitro contracture test, Succinylcholine, Volatile anesthetics

\section{Background}

Malignant hyperthermia ( $\mathrm{MH})$ is mostly an inherited subclinical myopathy triggered by volatile anesthetics and depolarizing muscle relaxants in susceptible individuals, leading to a potentially lethal hypermetabolic reaction of skeletal muscle due to a disturbance of myoplasmic calcium homeostasis. Characteristic clinical signs of $\mathrm{MH}$ during a general anesthesia include hypoxemia, hypercapnia, tachycardia, muscular rigidity, acidosis, hyperkalemia and hyperthermia [1]. While expected genetic predisposition for $\mathrm{MH}$ is stated to be as frequent as 1:2.000, the prevalence of MH episodes varies regionally from 1:10.000 to $1: 220.000$

\footnotetext{
* Correspondence: schuster_f@klinik.uni-wuerzburg.de

Department of Anesthesia and Critical Care, University of Wuerzburg,

Oberduerrbacher Str. 6, D-97080 Wuerzburg, Germany
}

[2,3]. In contrast to fulminant $\mathrm{MH}$ episodes, abortive courses might occur more frequently, but are difficult to diagnose due to the alleviated symptoms.

Recent developments in anesthesiology apparently have lead to a decrease in severe $\mathrm{MH}$ crisis over the last years: Halothane, a potent $\mathrm{MH}$ triggering agent, is no longer used in clinical routine in western countries [4] and currently applied volatile anesthetics, e.g. isoflurane, sevoflurane or desflurane, in some cases significantly decelerate the onset of an $\mathrm{MH}$ reaction compared to halothane $[5,6]$ and are more likely to lead to abortive $\mathrm{MH}$ with eased symptoms. Furthermore, the recommended indications for succinylcholine, another possible $\mathrm{MH}$ triggering agent, have been limited by international anesthesia societies [7].

\section{Biomed Central}

(C) 2013 Schuster et al.; licensee BioMed Central Ltd. This is an Open Access article distributed under the terms of the Creative Commons Attribution License (http://creativecommons.org/licenses/by/2.0), which permits unrestricted use, distribution, and reproduction in any medium, provided the original work is properly cited. 
Considering all these facts, the aim of the present study was to investigate, whether $\mathrm{MH}$ is still a relevant anesthetic problem in our days.

\section{Methods}

With approval of the local ethics committee (application number: 263/11, ethics committee of the University of Wuerzburg) data of patients who where referred to the $\mathrm{MH}$ unit of the Department of Anesthesia and Critical Care of the University of Wuerzburg for diagnostic muscle biopsy and subsequent in vitro contracture testing (IVCT) between 2007 and 2011 were evaluated. Based on available patient documents and medical records the intraoperative events were examined. To confirm the suspicion of an $\mathrm{MH}$ crisis, applied triggering agents, clinical symptoms e.g. cardiac arrhythmia, increase of end-tidal carbon dioxide $\geq 45 \mathrm{mmHg}$, rises of patients' body temperature $\geq 38.5^{\circ} \mathrm{C}$ and possible use of dantrolene were analyzed. Besides that, the medical records were reviewed for severe postoperative complications, e.g. neurological deficits, disseminated intravascular coagulation (DIC), acute renal failure or signs of rhabdomyolysis according to maximum creatine kinase (CK) levels. If blood gas analysis was implemented, $\mathrm{pH} \leq 7.2$, base excess $\leq-5 \mathrm{mmol} / \mathrm{l}$ and $\mathrm{PaCO}_{2} \geq 50 \mathrm{mmHg}$ defined a severe metabolic response. Only patients with a suspected $\mathrm{MH}$ episode during general anesthesia due to the estimation of the responsible anesthesiologist, completed IVCT and genetic analysis of the ryanodine receptor gene were included in the investigation.

In referred patients a diagnostic IVCT with increasing caffeine and halothane concentrations in separated tissue baths was performed according to the guidelines of the European $\mathrm{MH}$ Group [8]. A contracture $\geq 2 \mathrm{mN}$ at caffeine $2 \mathrm{mM}$ and halothane $0.44 \mathrm{mM}$ lead to the diagnosis $\mathrm{MH}$ susceptible (MHS). If significant contractures occurred after one of the drugs only, patients were classified as $\mathrm{MH}$ equivocal (MHE, MHE for halothane (MHEh) or caffeine MHEc). If no significant contracture was observed the patients were rated $\mathrm{MH}$ non-susceptible (MHN).

In addition, for each patient, the clinical grading scale (CGS) by Larach and colleagues, which includes metabolic and muscular parameters as well as changes in cardiac rhythm and body temperature, was applied retrospectively. According to the grading scale 3 to 15 points were calculated for each parameter and added to receive a score. This score allowed allocation to individual $\mathrm{MH}$-ranks $(0=\mathrm{MH}$ almost never, 3-9 $=\mathrm{MH}$ unlikely, $10-19=\mathrm{MH}$ somewhat less than likely, 20-34 $=\mathrm{MH}$ somewhat greater than likely, 35-49 $=\mathrm{MH}$ very likely, $>50=\mathrm{MH}$ almost certain) [9].

\section{Results}

Between 2007 and 2011 a total of 124 patients underwent a muscle biopsy followed by IVCT at the MH lab of the
University of Wuerzburg. Overall 19 of these patients had been referred to the $\mathrm{MH}$ unit because of a suspected $\mathrm{MH}$ event during general anesthesia on the basis of estimation of the attending anesthesiologists. In the remaining patients $\mathrm{MH}$ diagnostics were initiated due to $\mathrm{MH}$ susceptibility in the family history, an unexplained rhabdomyolysis or to exclude a myopathic disorder in association with persistently elevated CK levels.

\section{Diagnostic findings}

Muscle biopsy and IVCT detected MH susceptibility in 7 (37\%; 7 male) of the 19 patients. In 8 patients $(42 \% ; 3$ male, 5 female) $\mathrm{MH}$ susceptibility could be excluded. Muscle bundles of 4 patients (21\%; 1 male, 3 female) developed a pathologic contracture only after exposure to halothane but not after caffeine (MHEh). Interestingly, initial applied CGS rated the probability of an MH crisis as "almost certain" ( $>50$ points) in 2 MHS patients and "very likely" (35 - 49 points) in 5 MHS and 1 MHEh patients, while in 3 MHEh patients the likelihood was classified as "less than likely" (10 - 19 points). Noteworthy, MH was assumed "greater than likely" (20 - 34 points) in $6 \mathrm{MHN}$ patients and "less than likely" or "almost never" in $1 \mathrm{MHN}$ patient each by CGS. Genetic screening detected mutations in the ryanodine receptor gene (Gly4037Alafs, Glu2174Ala, Val4234Leu) of 3 MHS patients. In 16 (84\%) patients the suspected MH event occurred between 2006 and 2010 (6 MHS, 3 MHEh, 7 MHN). The remaining 3 patients had been 10 years old or younger at the time of incident $(1992,1995,1998)$ and therefore muscle biopsy in these patients was delayed until the age of 16 years according to our hospital standard operating procedures. Since the MH diagnostic was performed within the study period, these 3 patients were included in the evaluation, even if the applied triggers were halothane or enflurane respectively. Interestingly, $2 \mathrm{MHS}$ individuals with suspected $\mathrm{MH}$ in their history had undergone at least one uneventful general anesthesia in the past. The histopathological examinations revealed a myopathic tissue syndrome in combination with cell clumps indicating a possibly neurogenic component in 1 MHEh patient, who had received succinylcholine as sole trigger agent. In the other patients there was no evidence of a muscular pathology (Table 1).

\section{Trigger agents and clinical presentations}

Only $21 \%$ of the MH suspected patients solely received an inhalation anesthetic (sevoflurane: $1 \mathrm{MHS}$; isoflurane: $1 \mathrm{MHN}$; desflurane: $2 \mathrm{MHN}$ ), while in $47 \%$ of the cases (6 MHS, 1 MHEh, $2 \mathrm{MHN}$ ) a combination of succinylcholine with a volatile anesthetic, e.g. halothane (1 MHEh), enflurane $(1 \mathrm{MHN})$ isoflurane (3 MHS, $1 \mathrm{MHN}$ ), sevoflurane (2 MHS) or desflurane (1 MHS) was used. In $28 \%$ (3 MHEh, 3 MHN) succinylcholine was applied as only $\mathrm{MH}$ trigger. Masseter spasm was observed in $63 \%$ of the 
Table 1 Diagnostic findings

\begin{tabular}{|c|c|c|c|c|c|c|c|c|}
\hline No & Age/sex & IVCT & Year of incidence & Surgery & Prev. Anesth. & Genetic status & CGS & Histopathology \\
\hline 1 & $46 \hat{0}$ & MHS & 2010 & Liposuction & 1 & Negative & 48 & WPF \\
\hline 2 & $58 \widehat{0}$ & MHS & 2010 & Spongiosaplasty & 2 & Gly4037Alafs & 38 & WPF \\
\hline 3 & $36 \hat{\jmath}$ & MHS & 2010 & Urachal fistula & - & Negative & 43 & WPF \\
\hline 4 & $14 \hat{0}$ & MHS & 2009 & Lower leg fracture & - & Glu2174Ala & 53 & WPF \\
\hline 5 & $18 \sigma^{-1}$ & MHS & 2008 & Gunshot injury & - & Val4234Leu & 53 & WPF \\
\hline 6 & $45 \hat{0}$ & MHS & 2007 & Hemilaminectomy & - & Negative & 38 & WPF \\
\hline 7 & $100^{\lambda}$ & MHS & 1995 & Appendectomies & - & Negative & 40 & WPF \\
\hline 8 & 62 안 & MHEh & 2009 & Bursectomy & - & Negative & 15 & WPF \\
\hline 9 & 32 우 & MHEh & 2009 & Caesarean section & - & Negative & 40 & Myopathy \\
\hline 10 & 29 우 & MHEh & 2006 & Uterine abrasion & - & Negative & 15 & WPF \\
\hline 11 & $3 \hat{0}$ & MHEh & 1992 & Tonsillectomy & - & Negative & 18 & WPF \\
\hline 12 & 35 우 & $\mathrm{MHN}$ & 2011 & Uterine abrasion & 2 & Negative & 18 & WPF \\
\hline 13 & $54 \mathrm{o}^{\lambda}$ & MHN & 2010 & Aortocoronary bypass & - & Negative & 30 & WPF \\
\hline 14 & 46 우 & MHN & 2009 & Uterine abrasion & 1 & Negative & 30 & WPF \\
\hline 15 & 34 안 & MHN & 2008 & Colon resection & - & Negative & 25 & WPF \\
\hline 16 & 57 우 & $\mathrm{MHN}$ & 2007 & Inguinal hernia & - & Negative & 30 & WPF \\
\hline 17 & $21+9$ & MHN & 2007 & Mandible fracture & - & Negative & 0 & WPF \\
\hline 18 & $39 \hat{0}$ & MHN & 2006 & Appendectomies & - & Negative & 30 & WPF \\
\hline 19 & 30 & MHN & 1998 & Orchidopexy & - & Negative & 30 & WPF \\
\hline
\end{tabular}

Age Patients' age MH-suspected episode occurred, IVCT In vitro contracture test, § Male, ㅇ Female, MHS Malignant hyperthermia susceptible, MHN Malignant hyperthermia non-susceptible, MHEh Malignant hyperthermia equivocal to halothane, WPF Without pathological finding.

patients (2 MHS, $4 \mathrm{MHEh}, 6 \mathrm{MHN}$ ), thereof in $28 \%$ of the cases (3 MHEh, $3 \mathrm{MHN}$ ) after succinylcholine administration. Based on the available patient records, application of volatile anesthetics or succinylcholine was stopped in all of the 19 patients and anesthesia was continued intravenously.

Cardiac arrhythmias were reported in $42 \%$ of the 19 cases. Hereof, an unexplained sinus tachycardia with heart rates between 90 to 135 per minutes were documented in $38 \%$ of the patients (3 MHS), while in $62 \%$ (2 MHS, 1 MHEh, 2 MHN) tachyarrhythmia were observed. In $11 \%$ of the patients, who received sevoflurane (1 MHS) or succinylcholine (1 MHEh) solely no arrhythmias were seen. In the remaining suspected cases the cardiac rhythm was not documented in patients' medical records. An increase of end-tidal carbon dioxide $>45 \mathrm{mmHg}$ during the course of anesthesia was noticed in $42 \%$ (5 MHS, $3 \mathrm{MHN})$. However, body temperature increases $\geq 38.5^{\circ} \mathrm{C}$ were only reported in $11 \%$ of the analyzed cases (1 MHS, $1 \mathrm{MHN}$ ). In $47 \%$ of the $\mathrm{MH}$ suspected cases (7 MHS, $1 \mathrm{MHEh}, 1 \mathrm{MHN}$ ) an increase of CK levels $>10.000 \mathrm{U} / \mathrm{L}$ following $\mathrm{MH}$ trigger application was observed. Despite the suspected $\mathrm{MH}$ diagnosis, dantrolene was administered only in 37\% (5 MHS, 1 MHEh, $1 \mathrm{MHN}$ ) for treatment of the observed symptoms (Table 2 ).

According to the medical records of the referred patients, no persistent or temporary complications e.g. DIC, acute renal failure or neurological deficits were reported during recovery after the suspected $\mathrm{MH}$ episode.

\section{Blood gas analysis}

Interestingly, in only $37 \%$ of the patients with suspected $\mathrm{MH}$ event an arterial blood gas analysis was documented to verify the assumed $\mathrm{MH}$ diagnosis. However, a relevant metabolic acidosis with $\mathrm{pH} \leq 7.2$, base excess $\leq-5 \mathrm{mmol} / \mathrm{l}$ and $\mathrm{PaCO}_{2} \geq 50 \mathrm{mmHg}$ was observed in 21\% (3 MHS, $1 \mathrm{MHN})$. Besides that, serum potassium levels were remarkable elevated $\geq 5 \mathrm{mmol} / \mathrm{l}$ in $16 \%$ of the cases ( $2 \mathrm{MHS}$, $1 \mathrm{MHN}$ ) (Table 3).

\section{Discussion}

Even though $\mathrm{MH}$ is a rare complication of general anesthesia, the presented cases clearly demonstrate that this life threatening muscular hypermetabolism is still a relevant risk requiring immediate and consequent treatment by the responsible anesthesiologist to avoid serious harm to the patient.

After the first description of $\mathrm{MH}$ by Denborough numerous cases of fulminant $\mathrm{MH}$ as well as in vitro investigations had been published in the following years, identifying halothane and succinylcholine as potential $\mathrm{MH}$ triggering agents [10]. While the metabolic deterioration in the course of an $\mathrm{MH}$ crisis induced by halothane seems to be a direct consequence of an interaction with 
Table 2 Applied trigger agents and clinical presentations of malignant hyperthermia suspected events

\begin{tabular}{|c|c|c|c|c|c|c|c|c|}
\hline No & IVCT & Trigger agents & Masseterspasm & $\begin{array}{l}\text { Dantrolene } \\
\text { application }\end{array}$ & $\begin{array}{l}\text { Cardiac } \\
\text { arrhythmia }\end{array}$ & $\begin{array}{l}\text { Max. end-tidal } \\
\mathrm{CO}_{2}[\mathrm{mmHg}]\end{array}$ & Max. temperature & $\begin{array}{l}\text { Max. Creatine } \\
\text { kinase [U/L] }\end{array}$ \\
\hline 1 & MHS & Isoflurane + SCh & Unknown & $1 \times 200 \mathrm{mg}$ & $\begin{array}{l}\text { Sinus } \\
\text { tachycardia }\end{array}$ & $48 \mathrm{mmHg}$ & $38.8^{\circ} \mathrm{C}$ & 10.514 \\
\hline 2 & MHS & Isoflurane $+\mathrm{SCh}$ & Yes & $1 \times 240 \mathrm{mg}$ & Tachyarrhythmia & $54 \mathrm{mmHg}$ & $36.1^{\circ} \mathrm{C}$ & $>10.000$ \\
\hline 3 & MHS & Sevoflurane + SCh & Yes & No & $\begin{array}{l}\text { Sinus } \\
\text { tachycardia }\end{array}$ & Unknown & Unknown & 51.557 \\
\hline 4 & MHS & Sevoflurane + SCh & Unknown & $2 \times 200 \mathrm{mg}$ & $\begin{array}{l}\text { Sinus } \\
\text { tachycardia }\end{array}$ & $62 \mathrm{mmHg}$ & Unknown & 23.700 \\
\hline 5 & MHS & Desflurane + SCh & Unknown & $1 \times 220 \mathrm{mg}$ & Tachyarrhythmia & $56 \mathrm{mmHg}$ & $37.6^{\circ} \mathrm{C}$ & $\approx 80.000$ \\
\hline 6 & MHS & Sevoflurane & No & $1 \times 200 \mathrm{mg}$ & No & $85 \mathrm{mmHg}$ & $37.5^{\circ} \mathrm{C}$ & 38.762 \\
\hline 7 & MHS & Isoflurane + SCh & Unknown & No & Unknown & Unknown & Unknown & 16.412 \\
\hline 8 & MHEh & $\mathrm{SCh}$ & Yes & $1 \times 200 \mathrm{mg}$ & Unknown & $39 \mathrm{mmHg}$ & Unknown & 119.150 \\
\hline 9 & MHEh & $\mathrm{SCh}$ & Yes & Unknown & No & $36 \mathrm{mmHg}$ & Unknown & 162 \\
\hline 10 & MHEh & SCh & Yes & No & Unknown & Unknown & Unknown & 2.234 \\
\hline 11 & MHEh & Halothane + SCh & Yes & Unknown & Tachyarrhythmia & Unknown & Unknown & Low \\
\hline 12 & $\mathrm{MHN}$ & SCh & Yes & No & Tachyarrhythmia & Unknown & Unknown & 132 \\
\hline 13 & MHN & Isoflurane & Yes & No & Unknown & $54 \mathrm{mmHg}$ & Unknown & 4.100 \\
\hline 14 & $\mathrm{MHN}$ & SCh & Yes & No & Unknown & Unknown & Unknown & 24.732 \\
\hline 15 & MHN & Desflurane & No & $1 \times 180 \mathrm{mg}$ & Tachyarrhythmia & $72 \mathrm{mmHg}$ & Unknown & Unknown \\
\hline 16 & $\mathrm{MHN}$ & SCh & Yes & No & Unknown & Unknown & Unknown & Unknown \\
\hline 17 & $\mathrm{MHN}$ & Desflurane & No & No & Unknown & Unknown & $38,5^{\circ} \mathrm{C}$ & Unknown \\
\hline 18 & MHN & Isoflurane + SCh & Yes & No & Unknown & $41 \mathrm{mmHg}$ & Unknown & 5.174 \\
\hline 19 & MHN & Enflurane + SCh & Yes & No & Unknown & $75 \mathrm{mmHg}$ & Unknown & 4.820 \\
\hline
\end{tabular}

IVCT In vitro contracture test, MHS Malignant hyperthermia susceptible, MHN malignant hyperthermia non-susceptible, MHEh Malignant hyperthermia equivocal to halothane, SCh Succinylcholine, $\mathrm{CO}_{2}$ Carbon dioxide.

the sarcoplasmic ryanodine receptor, the pathophysiological mode of action of succinylcholine has remained unknown. For instance, in vitro succinylcholine increased halothaneinduced muscular contractions of MHS patients, but no contracture could be observed after exposition to succinylcholine alone [11]. Even systemic application of succinylcholine could not reproducibly elicit an $\mathrm{MH}$ episode in susceptible swine [12,13]. In humans, according to an evaluation of the North American MH Registry and a

Table 3 Blood gas analysis of malignant hyperthermia suspected events

\begin{tabular}{llllll}
\hline No & IVCT & pH & BE $[\mathrm{mmol} / \mathbf{l}]$ & $\mathrm{PaCO}_{\mathbf{2}}[\mathrm{mmHg}]$ & Potassium [mmol/l] \\
\hline 1 & MHS & 7.20 & - & 50 & - \\
3 & MHS & 7.19 & -7 & 55 & 3.9 \\
5 & MHS $^{*}$ & 7.38 & 1 & 46 & 6.3 \\
10 & MHS & 7.17 & $-3,8$ & 72 & 5.0 \\
15 & MHN & 7.20 & $-7,9$ & 69 & 7.3 \\
17 & MHN & 7.30 & - & 38 & 4.1 \\
19 & MHN & 7.30 & - & - & -
\end{tabular}

IVCT In vitro contracture test, MHS Malignant hyperthermia susceptible, $M H N$ Malignant hyperthermia non-susceptible, $\mathrm{BE}$ Base excess, $\mathrm{PaCO}_{2}$ Arterial carbon dioxide pressure.

*blood gas analysis after admission at the intensive care unit. recently performed European multicentric study, succinylcholine triggered $\mathrm{MH}$ in absence of an inhalation anesthetic only in $0.7 \%$ or $1 \%$ respectively of the investigated cases $[14,15]$. Since the definitively underlying mode of action of succinylcholine to elicit MH remains unclear so far, the pharmacological characteristics of this agent may enable a possible explanation of it's role to induce $\mathrm{MH}$. Following intravenous application succinylcholine activates the nicotinergic acetylcholine receptor and provokes a local depolarization of the cell membrane. The transient depolarization of voltage-gated receptors in combination with an influx of extracellular calcium via acetylcholine receptors could lead to a significant increase of intracellular calcium concentrations and after exceeding a certain threshold $\mathrm{MH}$ may occurs in affected individuals. In this context, muscular fasciculation and rigidity caused by succinylcholine was considered to be causal for $\mathrm{MH}$. Consequently, a masseter spasm following succinylcholine was postulated to be an early sign of an imminent $\mathrm{MH}$ episode. However, specificity of this clinical sign is limited due to the subjective appraisal and the fact, that jaw tightness is a common side effect of succinylcholine, but only in half of the patients associated with $\mathrm{MH}$ susceptibility [16]. Similar results were obtained in our investigation. 
MH susceptibility was confirmed in only $50 \%$ of the suspected $\mathrm{MH}$ cases, where a succinylcholine-induced masseter spasm was noticed. Interestingly, histological examination of 1 MHEh patient who solely received succinylcholine revealed suspected myopathological finding. Although, neuromuscular disorders are common in MHE patients [17], it remains unclear, if these muscular alterations were responsible for the increased sensitivity to succinylcholine in this patient.

Generally, the likelihood of succinylcholine-induced $\mathrm{MH}$ seems to be extremely low, however there is little doubt, that combination with a volatile anesthetic potentiates the onset and the clinical symptoms of an $\mathrm{MH}$ event [18]. Remarkably, despite the possibly serious side-effects like $\mathrm{MH}$, hyperkalemia or cardiac arrest, succinylcholine was actually applied to secure the airway in $79 \%$ of the referred patients. In part, this approach was reasonable due the higher risk of aspiration in case of trauma or abdominal surgery. However, according to published guidelines the use of the non-depolarizing muscle relaxant rocuronium and if needed followed by application of sugammadex to reverse the neuromuscular blockade might be an adequate alternative to avoid succinylcholine associated adverse effects $[7,19]$.

In contrast to succinylcholine, the impact of all inhalation anesthetics used in daily clinical routine in the development of an $\mathrm{MH}$ crisis is beyond dispute. However, dependent on the applied volatile anesthetic the time interval between induction of anesthesia and clinical symptoms of an $\mathrm{MH}$ episode seems to vary. For instance, Hopkins and colleagues reported, that in susceptible patients the onset of $\mathrm{MH}$ was statistically significant faster after halothane exposure compared to enflurane or sevoflurane [5]. Equally, fulminant $\mathrm{MH}$ episodes after isoflurane, sevoflurane or desflurane seem to occur with temporal delay [20,21], while halothane may induce $\mathrm{MH}$ within minutes [5]. In MHS animals, similar results were seen after intramuscular injection of halothane or sevoflurane. The induced local hypermetabolic responses measured by local muscular lactate and carbon dioxide pressure increase were more distinct after halothane than after sevoflurane application [22,23]. Furthermore, in vitro the effect on muscular contractures of MHS muscle bundles varies between halothane and modern volatile anesthetics at equivalent concentrations [24]. These different clinical appearances of $\mathrm{MH}$ following volatile anesthetic application might be caused due to differences in the calcium releasing potency of these diverse agents. For example, sarcoplasmic calcium release at cellular level was significant smaller after sevoflurane or desflurane exposure compared to equimolar halothane concentrations $[25,26]$. In the analyzed anesthetic events of the present evaluation, $\mathrm{MH}$ episodes were induced by established $\mathrm{MH}$ triggers like halothane or isoflurane as well as by modern volatile anesthetics, e.g. sevoflurane or desflurane. Although, in the majority of the cases inhalation anesthetics were combined with succinylcholine and only in one case sevoflurane was applied solely, our findings emphasized the $\mathrm{MH}$ trigger potency of newer volatile anesthetics.

Beside masseter spasm cardiac arrhythmias are further early symptoms of imminent MH. Equally to a retrospective analysis from the United States, where the incidence was estimated 40\% [14], in the presented investigation the occurrence of unexplained cardiac alterations was $42 \%$. On closer examination the incidence of cardiac symptoms was even higher in the MHS group with either sinus tachycardia or tachyarrythmia as the leading signs.

The low incidence of testified metabolic acidosis might be attributed to the failure to obtain arterial blood gas analysis in the acute phase of the $\mathrm{MH}$ reaction or due to dantrolene pretreatment. For example, one patient's blood gas analysis was performed not until the arrival on the intensive care unit and after treatment with dantrolene, showing an unremarkable blood acid status, while in contrast the intraoperative end-tidal carbon dioxide increased relevant to $56 \mathrm{mmHg}$ in this patient. Overall, in only $37 \%$ of the MH suspected cases a blood gas analysis was conducted to verify the suspected diagnosis. This line of action is remarkable, since the presence of an acidosis supports the reasonable suspicion of $\mathrm{MH}$ in these cases.

Hyperthermia is a dramatic but often late sign of $\mathrm{MH}$, reflecting the proceeding metabolic breakdown in affected individuals. Hence, temperature monitoring during general anesthesia is recommended if $\mathrm{MH}$ triggers are used, since in a couple of cases hyperthermia was the only sign of $\mathrm{MH}$ [14]. Fulminant MH episodes may be marked by a rapid increase in body temperature at a rate of $1-2^{\circ} \mathrm{C}$ every five minutes [27]. Stunningly, only in $11 \%$ of the suspected $\mathrm{MH}$ cases (1 MHS and $1 \mathrm{MHN}$ ) a remarkable hyperthermia with an increase in core temperature $\geq 38.5^{\circ} \mathrm{C}$ was noticed. The overall low incidence of core temperature rises in the presented study might be attributable to the initiated dantrolene treatment or the possible absence of temperature monitoring.

The pathological changes during $\mathrm{MH}$ crisis are based on an uncontrolled increase of myoplasmic calcium, resulting in an ongoing skeletal muscular contracture and loss of cellular integrity leading to hyperkalemia and rhabdomyolysis [28]. Although the surgical trauma itself might cause a significant increase in CK levels, postoperative unexplained excessive hyperCKemia should lead to a diagnostic workup to exclude $\mathrm{MH}$ susceptibility as underlying pathology. The reason for the remarkable CK increase up to $24.732 \mathrm{U} / \mathrm{L}$ in one of the MHN patients following succinylcholine remains unclear. A not yet diagnosed myopathy could not definitely be excluded, but based on the advanced age of the patient 
and the inconspicuous histological findings it seems very unlikely.

In contrast to the estimation, that nearly $70 \%$ of $\mathrm{MH}$ families carry mutations in the ryanodine receptor gene [29], the genetic prevalence of $27 \%$ in the analyzed MHS cases was overall low. Noteworthy, even if the Val4234Leu variant of one MHS patient has recently been mentioned in context of a novel exome sequencing method for $\mathrm{MH}$ relevant mutations [30], none of the detected genetic variants had been accepted as causative for $\mathrm{MH}$ according to the European MH Group database, which includes so far 31 approved mutations of the more than 200 identified ryanodine receptor gene variants [31]. However, it is important to mention, that absence of a causative mutation does not reliably exclude MH susceptibility. To confirm or exclude $\mathrm{MH}$ a muscle biopsy followed by an IVCT must be carried out in these patients [32].

After introduction of dantrolene in clinical use a causal treatment of $\mathrm{MH}$ has been available since the late 1970's. The mode of action of this drug is based on inhibition of the sarcoplasmic reticulum calcium release without increasing the reuptake of calcium ions into the sarcoplasmic reticulum [33]. According to current guidelines application of dantrolene is an essential part in the treatment of an $\mathrm{MH}$ crisis $[34,35]$. However, only $37 \%$ of the patients in the presented investigation received dantrolene for causal MH therapy. Nevertheless, the importance of consequent dantrolene treatment is absolutely clear [36], even if the hypermetabolic state in some of the presented cases was already terminated by discontinuation of $\mathrm{MH}$ trigger substances.

Once surviving fulminate $\mathrm{MH}$ episodes several reports documented severe complications, e.g. acute renal failure from rhabdomyolysis, DIC, congestive heart failure or intestinal ischemia due to the uncontrolled metabolic reaction and myocyte death [27]. Fortunately, the review of the medical records of the referred patients, did not detect any serious harms to the patients after an $\mathrm{MH}$ episodes, which importantly delayed recovery.

To draw conclusions about the likelihood of $\mathrm{MH}$ among the suspected incidents, the "Clinical Grading Scale" (CGS) established by Larach and colleagues assessed clinical and metabolic parameters, e.g. muscle rigidity, rhabdomyolysis, acidosis, increases in body temperature and cardiac arrhythmias [9]. The validity of the CGS may be reduced due to limited availability of complete data sets and hence, often does not satisfactorily correlate with the IVCT results [37]. The false negatives as well as the false positive diagnosis obtained by CGS calculation in our analysis are likely a result of the fragmentary available medical records. Thus, sole evaluation of the CGS seems not to be adequate to prove $\mathrm{MH}$ susceptibility.

Finally, anesthesiologists must be aware that uneventful previous general anesthesia does not exclude $\mathrm{MH}$ susceptibility [14]. For instance, two of the MHS patients reported a history of exposure anesthesia in the past. The reason why some patients develop $\mathrm{MH}$ after first exposition to $\mathrm{MH}$ triggering agents, while others do not, still remains unclear and might be explained by an individual cellular compensation mechanism lowering myoplasmic calcium concentrations.

\section{Conclusions}

Analysis of the presented data might be limited by partly incomplete documentation as well as the individual interpretation. Nevertheless, in conclusion $\mathrm{MH}$ still is a relevant complication these days and every anesthesiologist must be prepared to recognize the symptoms of $\mathrm{MH}$ crisis and to start sufficient treatment. While fulminate courses of $\mathrm{MH}$ are easy to diagnose, abortive presentations with solitary or alleviated symptoms are more difficult to detect and pose an enormous challenge to the attending anesthesiologist. The initiation of an adequate and consequent treatment including the application of dantrolene and termination of $\mathrm{MH}$ trigger application is essential for patients' prognosis and survival. Besides that, every patient after a suspected $\mathrm{MH}$ event should be referred to a $\mathrm{MH}$ center for further counseling.

\section{Abbreviations}

CGS: Clinical grading scale; CK: Creatine kinase; IVCT: In vitro contracture test; $\mathrm{MH}$ : Malignant hyperthermia; MHEh: Malignant hyperthermia equivocal to halothane; MHN: Malignant hyperthermia non-susceptible; MHS: Malignant hyperthermia susceptible.

\section{Competing interests}

The authors declare that they have no competing interests.

\section{Authors' contributions}

FS conceived the study, accompanied the data acquisition, collected and analyzed the data and drafted the manuscript. SJ collected data and helped writing the manuscript. DS collected data. NR participated in the design of the study. All authors read and approved the final manuscript.

\section{Acknowledgements}

Chief technician Judith Skirde (Malignant Hyperthermia laboratory, University of Wuerzburg, Germany) contributed essential advice and technical assistance throughout the study.

The authors would like to thank Miss Carola Fricke for proofreading the manuscript.

The study was performed at the Department of Anesthesia and Critical Care at the University of Wuerzburg, Germany.

Publication of this investigation was funded by the German Research Foundation (DFG) and the University of Wuerzburg in the funding programme Open Access Publishing.

Received: 20 November 2012 Accepted: 19 September 2013 Published: 23 September 2013

References

1. Bandschapp O, Girard T: Malignant hyperthermia. Swiss Med Wkly 2012, 31:142.

2. Monnier N, Krivosic-Horber R, Payen JF, Kozak-Ribbens G, Nivoche Y, Adnet $P$, Reyford $H$, Lunardi J: Presence of two different genetic traits in malignant hyperthermia families: implication for genetic analysis, diagnosis, and incidence of malignant hyperthermia susceptibility. Anesthesiology 2002, 97:1067-1074. 
3. Ording $\mathrm{H}$ : Epidemiology of malignant hyperthermia. In Malignant hyperthermia. Edited by Schulte Am Esch J, Scholz J, Wappler F. Lengerich: Pabst Science Publishers; 2000:26-29.

4. Bundesinstitut für Arzneimittel und Medizinprodukte: Bekanntmachung der Erlöschung fiktiver Arzneimittelzulassungen nach \$105 Abs. 3 Satz 1 des Arzneimittelgesetzes. Bundesanzeiger 2001, 11:61-62.

5. Hopkins PM: Malignant hyperthermia: pharmacology of triggering Br J Anaesth 2011, 107:48-56.

6. Wedel DJ, Gammel SA, Milde JH, laizzo PA: Delayed onset of malignant hyperthermia induced by isoflurane and desflurane compared with halothane in susceptible swine. Anesthesiology 1993, 78:1138-1144.

7. DGAl info: Aktualisierte Stellungsnahme der DGAl. Verwendung von Succinylcholin. Anästh Intensivmed 2008, 43:831.

8. The European Malignant Hyperpyrexia Group: A protocol for the investigation of malignant hyperpyrexia (MH) susceptibility. $\mathrm{Br} J$ Anaesth 1984, 56:1267-1269.

9. Larach MG, Localio AR, Allen GC, Denborough MA, Ellis FR, Gronert GA Kaplan RF, Muldoon SM, Nelson TE, Ording H: A clinical grading scale to predict malignant hyperthermia susceptibility. Anesthesiology 1994, 80:771-779.

10. Denborough MA, Forster JF, Lovell RR, Maplestone PA, Villiers JD: Anaesthetic deaths in a family. Br J Anaesth 1962, 34:395-396.

11. Galloway GJ, Denborough MA: Suxamethonium chloride and malignant hyperpyrexia. Br J Anaesth 1986, 58:447-450.

12. laizzo PA, Wedel DJ: Response to succinylcholine in porcine malignant hyperthermia. Anesth Analg 1994, 79:143-151.

13. Nelson TE, Jones EW, Bedell DM: Porcine malignant hyperthermia: a study on the triggering effects of succinylcholine. Anesth Analg 1973, 52:908-911.

14. Larach MG, Gronert GA, Allen GC, Brandom BW, Lehman EB: Clinical presentation, treatment, and complications of malignant hyperthermia in north America from 1987 to 2006. Anesth Analg 2010, 110:498-507.

15. Heiderich S: Multicentric clinical and genetic evaluation classifies succinylcholine as accelerant of confirmed malignant hyperthermia crises. In Presented as an abstract at the 31th Annual Meeting of the European Malignant Hyperthermia Group, Volume 31. Leeds, Great Britain; 2012:27.

16. O'Flynn RP, Shutack JG, Rosenberg H, Fletcher JE: Masseter muscle rigidity and malignant hyperthermia susceptibility in pediatric patients. An update on management and diagnosis. Anesthesiology 1994, 80:1228-1233.

17. Wappler F, Scholz J, von Richthofen V, Fiege M, Köchling A, Matschke J, Winkler G, Schulte am Esch J: Incidence of disposition for malignant hyperthermia in patients with neuromuscular diseases. Anasthesiol Intensivmed Notfallmed Schmerzther 1998, 33:373-380.

18. Pollock AN, Langton EE, Couchman K, Stowell KM, Waddington M: Suspected malignant hyperthermia reactions in New Zealand. Anaesth Intensive Care 2002, 30:453-461

19. Chambers D, Paulden M, Paton F, Heirs M, Duffy S, Craig D, Hunter J, Wilson J, Sculpher M, Woolacott N: Sugammadex for the reversal of muscle relaxation in general anaesthesia: a systematic review and economic assessment. Health Technol Assess 2010, 14:1-211.

20. Migita T, Mukaida K, Kobayashi M, Hamada H, Kawamoto M: The severity of sevoflurane-induced malignant hyperthermia. Acta Anaesthesiol Scand 2012, 56:351-356.

21. Hoenemann CW, Halene-Holtgraeve TB, Booke M, Hinder F, Daudel F, Reich A, Van Aken H: Delayed onset of malignant hyperthermia in desflurane anesthesia. Anesth Analg 2003, 96:165-167.

22. Schuster F, Schöll H, Hager M, Müller R, Roewer N, Anetseder M: The doseresponse relationship and regional distribution of lactate after intramuscular injection of halothane and caffeine in malignant hyperthermia-susceptible pigs. Anesth Analg 2006, 102:468-472.

23. Schuster F, Metterlein T, Negele S, Gardill A, Schwemmer U, Roewer N, Anetseder M: Intramuscular injection of sevoflurane detects malignant hyperthermia predisposition in susceptible pigs. Anesthesiology 2007, 107:616-620.

24. Metterlein T, Schuster F, Kranke P, Roewer N, Anetseder M: In-vitro contracture testing for susceptibility to malignant hyperthermia: can halothane be replaced? Eur J Anaesthesiol 2011, 28:251-255.

25. Kunst G, Graf BM, Schreiner R, Martin E, Fink RH: Differential effects of sevoflurane, isoflurane, and halothane on $\mathrm{Ca} 2+$ release from the sarcoplasmic reticulum of skeletal muscle. Anesthesiology 1999, 91:179-186.

26. Kunst G, Stucke AG, Graf BM, Martin E, Fink RH: Desflurane induces only minor $\mathrm{Ca} 2+$ release from the sarcoplasmic reticulum of mammalian skeletal muscle. Anesthesiology 2000, 93:832-836.

27. Rosenberg H, Davis M, James D, Pollock N, Stowell K: Malignant hyperthermia. Orphanet J Rare Dis 2007, 24(2):21.

28. Schuster F, Müller-Reible CR: Malignant hyperthermia-diagnostics, treatment and anaesthetic management. Anasthesiol Intensivmed Notfallmed Schmerzther 2009, 44:758-763.

29. Robinson R, Carpenter D, Shaw MA, Halsall J, Hopkins P: Mutations in RYR in malignant hyperthermia and central core disease. Hum Mutat 2006, 27:977-989.

30. Kim JH, Jarvik GP, Browning BL, Halsall J, Hopkins PM: Exome sequencing and identity by descent (IBD) analysis in malignant hyperthermia gene discovery. Anesthesiology 2011, A:1572.

31. European Malignant Hyperthermia Group: Causative RyR1 mutations. 2013. http://www.emhg.org/genetics/mutations-in-ryr1/.

32. Urwyler A, Deufel T, McCarthy T, West S, European Malignant Hyperthermia Group: Guidelines for molecular Genetic detection of susceptibility to malignant hyperthermia. Br J Anaesth 2001, 86:283-287.

33. Gerbershagen MU, Fiege M, Krause T, Agarwal K, Wappler F: Dantrolene. Pharmacological and therapeutic aspects. Anaesthesist 2003, 52:238-245.

34. Glahn KP, Ellis FR, Halsall PJ, Müller CR, Snoeck MM, Urwyler A, Wappler F, European Malignant Hyperthermia Group: Recognizing and managing a malignant hyperthermia crisis: guidelines from the European malignant hyperthermia group. Br J Anaesth 2010, 105:417-420.

35. Schuster $F$, Johannsen $S$, Roewer N: Deklaration von Helsinki zur Patientensicherheit in der Anästhesiologie: SOP zur Malignen Hyperthermie. Anasthesiol Intensivmed Notfallmed Schmerzther 2013 48:162-164.

36. Burkman JM, Posner KL, Domino KB: Analysis of the clinical variables associated with recrudescence after malignant hyperthermia reactions. Anesthesiology 2007, 106:901-906.

37. von Richthofen V, Wappler F, Scholz J, Fiege M, Schulte Am Esch J: Evaluation of malignant hyperthermia episodes with the clinical grading scale. Anasthesiol Intensivmed Notfallmed Schmerzther 1998, 33:244-249.

doi:10.1186/1471-2253-13-24

Cite this article as: Schuster et al:: Evaluation of suspected malignant hyperthermia events during anesthesia. BMC Anesthesiology 2013 13:24.

\section{Submit your next manuscript to BioMed Central and take full advantage of:}

- Convenient online submission

- Thorough peer review

- No space constraints or color figure charges

- Immediate publication on acceptance

- Inclusion in PubMed, CAS, Scopus and Google Scholar

- Research which is freely available for redistribution

Submit your manuscript at www.biomedcentral.com/submit 